\title{
Herbaceous Vegetation Changes Following Applications of Tebuthiuron for Brush Control
}

\author{
C. J. SCIFRES AND J. L. MUTZ
}

Highlight: Aerial applications of $2.24 \mathrm{~kg} / \mathrm{ha}$ (active ingredient) of tebuthiuron pellets to mixed brush and whitebrush-dominated stands in South Texas significantly increased grass standing crops at 1,2 , and 3 years after treatment. Higher rates did not significantly increase grass standing crop over that resulting from $2.24 \mathrm{~kg} / \mathrm{ha}$; lower rates did not increase grass standing crop compared to that on untreated plots at two of three locations. The genus Chloris appears to be particularly tolerant of the herbicide, and by 2 to 3 years after application, the overall grazing value of the grass stand was improved where at least $2.24 \mathrm{~kg} / \mathrm{ha}$ of tebuthiuron were applied. Forb production and diversity were decreased where $1 \mathrm{~kg} / \mathrm{ha}$ or more of the herbicide was applied, and the detrimental effect on forbs increased with increasing application rate. Forb production was nearly eliminated for 2 years following application of $4.48 \mathrm{~kg} / \mathrm{ha}$ of tebuthiuron but recovery of the population was evident after 3 years regardless of rate of application.

The potential of spray drift damaging susceptible crops, stringent timing requirements for application of herbicide sprays relative to plant phenology, and differential responses of woody species in mixed stands has provided the impetus for researching dry formulations of herbicides for brush control. Since dry formulations are dependent upon root uptake for activity, timeliness and extent of rainfall and soil characteristics interact to regulate vegetation responses to any specific soil active herbicide.

Regardless of the type of brush management treatment, evaluation of undesirable plant responses only partially relates potential for range improvement. Concomittant responses of herbaceous forages, both in quantity and relative proportions by species, is needed to assess brush control effectiveness fully. For instance, differentials in brush control effectiveness of aerial sprays of 2,4,5-T ([2,4,5-trichlorophenoxyl]acetic acid) alone or in combination with dicamba (3,5-dichloro-o-anisic acid) or picloram (4-amino3,5,6-trichloropicolinic acid) were more fully expressed over several years when forage production, forage utilization, and efficiency of converting available moisture to herbaceous production were considered in conjunction with brush control response (Scifres et al. 1977). As contrasted

Authors are professor and research associate, Texas Agricultural Experiment Station (Department of Range Science), Texas A\&M University. College Station 77843.
This

This report is technical article TA-13768 from the Texas Agricultural Experiment Station. This research was supported in part by Lilly Research Laboratories, Greenfield, Indiana. The Chaparrosa Ranch, LaPryor; Leo Welder Ranch, Sinton; Dick Horton Ranch. Tilden; and Tom Haalf Ranch, Pearsall, Texas, provided land for the conduct of this research. The participation of Wayne T. Hamilton in the installation, evaluation, and interpretation of the research is appreciated. Soil surveys conducted by Michael Brown and Jack Stevens, Soil Conservation Service. Uvalde, were highly appreciated.

Manuscript received November 10, 1977. to foliar sprays, which may remove the brush foliage within a few weeks, woody plant response to dry formulations may not be completely manifested for a full growing season or longer.

Robison and Cross (1970) reported that aerial applications of picloram pellets to redberry juniper (Juniperus pinchoti Sudw.) stands not only significantly increased grass standing crop compared to untreated areas, but that after 2 years the proportion of the forage of good grazing value had increased. A relatively new herbicide, tebuthiuron ( $N$ - [5-(1,1-dimethylethyl)-1, 3, 4-thiadiazol-2-yl]- $N, N^{\prime}$-dimethylurea) has shown promise in south Texas for control of several woody species, many of which are not controlled or are only partially controlled with conventional herbicide sprays (Scifres, et al. 1978). The objective of this paper is to report the response of herbaceous species to aerial applications of tebuthiuron pellets where brush control efficacy was evaluated.

\section{Materials and Methods}

Sites near LaPryor, Sinton, and Tilden, Texas, as described by Scifres et al. (1978) were evaluated. Tebuthiuron pellets $(0.32-\mathrm{cm}$ diameter and $10 \%$ active ingredient [a.i.]) were aerially applied at $1.12,2.24,3.36$, and $4.48 \mathrm{~kg} / \mathrm{ha}$ on May 15,1974 , to plots $31 \mathrm{~m}$ by $322 \mathrm{~m}$ in a stand of mixed brush (Prosopis-Acacia) near LaPryor in the South Texas Plains. The experiment was designed as a randomized complete block with each treatment duplicated.

On September 25, 1975, tebuthiuron as the $20 \%$ a.i. pellets was aerially applied at 2 and $3.36 \mathrm{~kg} /$ ha to plots $51.2 \mathrm{~m}$ by $457.2 \mathrm{~m}$ in mixed brush near Sinton on the Coastal Prairie. On November 20,1975 , tebuthiuron pellets $(20 \%$ a.i. $)$ were aerially applied at 1 and $2 \mathrm{~kg} /$ ha to whitebrush (Aloysia lycioides)-dominated plots, $52 \mathrm{~m}$ by $483 \mathrm{~m}$, near Tilden on the South Texas Plains. Single plots including an untreated comparison were separated by buffer strips, about $20-\mathrm{m}$ wide, at locations near Sinton and Tilden. Treated areas at all locations were fenced to exclude grazing animals for the duration of the study.

On May 22, 1975; June 21, 1976; and July 20, 1977, herbaceous vegetation was evaluated in the experiment near LaPryor along sampling points equally spaced down the center of each plot. Within $2 \mathrm{~m}$ from each point, basal contacts with herbaceous vegetation were recorded from two, randomly located, inclined 10point frame samples. Herbaceous topgrowth, separated into grasses and forbs, was harvested from a $0.25-\mathrm{m}^{2}$ quadrat at each sampling point. Herbage samples were dried at $65^{\circ} \mathrm{C}$ for $48 \mathrm{hr}$ and weighed. Twenty-five sample points were established in each plot but only 20 points were utilized for vegetation analyses in 1976 and 1977. Using the same procedures as described for LaPryor, plots near Sinton were evaluated in August 1975, June 1976, and July 1977. Plots near Tilden were evaluated July 17, 1977. The only difference in evaluation of plots near Tilden and 
Sinton, compared to those near LaPryor, was that due to the heavy herbaceous cover, foliar instead of basal contacts were recorded using a point frame about $2 \mathrm{~m}$ tall.

Proportions of forages, using either foliar or basal contacts, depending on location, were characterized as good to excellent, fair, or poor grazing value based on assessments of Gould and Box (1965) and Hoffman et al. (1970).

Soils of the study site near LaPryor were Tonio sandy clay loam (fine loamy, mixed, hyperthermic Ustollic Haplargids) and Chacon clay loam (fine, montmorillonitic, hyperthermic Vertic Arguistolls). Soils of the Tilden site were Clareville loam (fine loamy, hyperthermic Pachic Arguistolls). Soil of the Sinton site was Willacy sandy loam (finc loamy, mixed, hyperthermic family of Udic Argiustolls).

The LaPryor site was dominated by mixed brush typified by a heavy cover of honey mesquite (Prosopis glandulosa var. glandulosa), whitebrush, twisted acacia (Acacia tortuosa), spiny hackberry (Celtis pallida), guajillo (Acacia berlandieri), and guayacan (Porlieria angustifolia). Associated species included Berlandier wolfberry (Lycium berlandieri var. berlandieri), javalinabrush (Microrhamnus ericoides), catclaw acacia (Acacia greggii), blackbrush acacia (Acacia rigidula), Texas colubrina (Colubrina texensis), desert yaupon (Schaefferia cunefolia), lotebush (Condalia obtusifolia), and allthorn (Koeberlina spinosa). The site near Sinton was dominated by huisache (Acacia farnesiana) and honey mesquite with a mixture of associated species including spiny hackberry, lime pricklyash (Zanthoxylum fagara), Texas persimmon (Diospyros texana), lotebush, pricklypear (Opuntia spp.), and tasajillo (Opuntia leptocaulis). The site near Tilden was dominated by whitebrush with scattered honey mesquite and spiny hackberry plants.

\section{Results and Discussion}

\section{Species Composition}

Almost 50 species of grasses were encountered on the study sites of which only six were common to all locations. Most were perennial, native, warm-season bunchgrasses. Within a location, only minor changes occurred in species present from initial to final evaluation, presumably due to under-sampling minor species. However, changes did occur in the relative proportions of the various species with time after treatment.

At initiation of the study near LaPryor, basal contacts of grasses averaged $9.7 \%$ of the total contacts with $43.9 \%$ bare ground, $41.2 \%$ mulch, and the remaining $5.2 \%$ afforded by broadleaves. Based on cover, composition of the grass stand relative to grazing value was unaffected by tebuthiuron application rate after 1 year near LaPryor (Table 1).

Table 1. Relative composition (\%) of grasses based on basal contacts in July-August for 3 years following application of tebuthiuron pellets at three rates to mixed brush near LaPryor, Texas, on May 20, 1974.

\begin{tabular}{lrrrrr}
\hline \hline \multirow{2}{*}{ Grazing value } & \multicolumn{5}{c}{ Tebuthiuron rate $(\mathrm{kg} / \mathrm{ha})$} \\
\cline { 2 - 6 } & 0 & 1.12 & 2.24 & 3.36 & 4.48 \\
\hline 1975 & & & & & \\
$\quad$ Good-Excellent & 13 & 18 & 12 & 14 & 14 \\
Fair & 72 & 76 & 73 & 76 & 79 \\
$\quad$ Poor & 15 & 6 & 15 & 10 & 7 \\
1976 & & & & & \\
Good-Excellent & 27 & 33 & 52 & 38 & 34 \\
Fair & 56 & 52 & 40 & 48 & 54 \\
$\quad$ Poor & 17 & 15 & 8 & 14 & 12 \\
1977 & & & & & \\
Good-Excellent & 27 & 56 & 69 & 51 & 62 \\
Fair & 71 & 33 & 24 & 40 & 34 \\
Poor & 2 & 11 & 7 & 9 & 4 \\
\hline
\end{tabular}

This was attributed to the normal time requirement for a measurable change in basal cover to occur, the relatively slow response of woody plants to soil-applied herbicides such as tebuthiuron, and dry growing conditions following herbicide application. Although the annual rainfall totalled $58.09 \mathrm{~cm}$, only $1.78 \mathrm{~cm}$ of precipitation occurred the first 90 days following herbicide application. However, the second year of study, due presumably to improved rainfall distribution (42.49 cm total for 1975 with $14.45 \mathrm{~cm}$ occurring during April and May) and protection from grazing, a higher proportion of the grass stand was afforded by species of good grazing value compared to composition the first year, regardless of treatment. Although there was a trend for a higher percentage of the stand to be composed of grasses of good grazing value following tebuthiuron application compared to untreated plots the second year after treatment with above normal rainfall $(66.91 \mathrm{~cm}$ total for 1976), treatment effects were most apparent after 3 years even under relatively dry growing conditions. From January 1 until evaluation in August 1977, $23.51 \mathrm{~cm}$ precipitation were received; but only $3.96 \mathrm{~cm}$ of that occurred in May, 3.42 fell in June, and none fell in July or August.

Since all plots were protected from grazing, improvement of untreated plots at 3 years after study initiation was reflected in absolute basal contacts of grasses affording $15.9 \%$ of the hits. In comparison, $17.2 \%$ of the contacts were grasses where $1.12 \mathrm{~kg} /$ ha of tebuthiuron were applied, $18.4 \%$ where $2.24 \mathrm{~kg} /$ ha were applied, $17.8 \%$ following the $3.36 \mathrm{~kg} / \mathrm{ha}$ application, and $19.8 \%$ where $4.48 \mathrm{~kg} / \mathrm{ha}$ of the herbicide were applied. The percentage bare ground decreased with time on all treated plots due primarily to increases in grass cover in response to brush control and increases in mulch cover afforded from leaf drop of herbicide-affected woody plants. Bare ground after 3 years averaged $28 \%$ where $2.24 \mathrm{~kg} /$ ha or more tebuthiuron were applied, compared to $42 \%$ on untreated plots near LaPryor.

The changes in proportions of grasses of good to excellent grazing value after tebuthiuron application near LaPryor (Table 2) was attributed primarily to increases in

Table 2. Oven-dry herbaceous standing crop (kg/ha) at 1,2 , and 3 years after aerial application of tebuthiuron at various rates to mixed brush near LaPryor, Texas.

\begin{tabular}{crrrrrr}
\hline \hline \multirow{2}{*}{$\begin{array}{c}\text { Year } \\
\text { after }\end{array}$} & \multicolumn{6}{c}{ Tebuthiuron rate $(\mathrm{kg} / \mathrm{ha})^{1}$} \\
\cline { 2 - 7 } treatment & 0 & 1.12 & 2.24 & 3.36 & 4.48 & Avg \\
\hline Grasses & & & & & & \\
1 & $1,491 \mathrm{~b}$ & $1,991 \mathrm{~b}$ & $2,855 \mathrm{c}$ & $3,014 \mathrm{~cd}$ & $2,398 \mathrm{t}$ & $2,640 \mathrm{c}$ \\
2 & $1,644 \mathrm{~b}$ & $1,727 \mathrm{~b}$ & $3,496 \mathrm{~d}$ & $3,636 \mathrm{~d}$ & $3,676 \mathrm{~d}$ & $2,836 \mathrm{t}$ \\
3 & $846 \mathrm{a}$ & $888 \mathrm{a}$ & $1,631 \mathrm{~b}$ & $1,529 \mathrm{~b}$ & $1,787 \mathrm{~b}$ & $1,336 \mathrm{u}$ \\
Avg & $1,327 \mathrm{r}$ & $1,535 \mathrm{r}$ & $2,660 \mathrm{~s}$ & $2,602 \mathrm{~s}$ & $2,825 \mathrm{~s}$ & \\
Forbs & & & & & & \\
1 & $585 \mathrm{l}$ & $59 \mathrm{hi}$ & $64 \mathrm{hi}$ & $16 \mathrm{~h}$ & $3 \mathrm{~h}$ & $145 \mathrm{y}$ \\
2 & $102 \mathrm{i}$ & $11 \mathrm{~h}$ & $27 \mathrm{hi}$ & $11 \mathrm{~h}$ & $1 \mathrm{~h}$ & $30 \mathrm{x}$ \\
3 & $486 \mathrm{l}$ & $469 \mathrm{kl}$ & $362 \mathrm{j}$ & $364 \mathrm{j}$ & $393 \mathrm{jk}$ & $415 \mathrm{z}$ \\
Avg & $391 \mathrm{v}$ & $180 \mathrm{w}$ & $151 \mathrm{w}$ & $130 \mathrm{w}$ & $132 \mathrm{w}$ & \\
\hline
\end{tabular}

1 Means followed by the same letter are not significantly different at the $95 \%$ level of confidence. Comparisons are possible within a forage separation relative to the rate by year interactions, the average influence of tebuthiuron rate, and the year means.

multiflowered false-rhodesgrass (Chloris pluriflora). Except for one plot which received $4.48 \mathrm{~kg} / \mathrm{ha}$ of tebuthiuron and in which multiflowered false-rhodesgrass afforded $5.6 \%$ of the cover, all plots supported $1 \%$ or less of the species at 1 year after treatment. Multiflowered false-rhodesgrass afforded $3.5 \%$ of the grass stand composition on untreated 
plots, based on basal contacts, and $11.5 \%$ and $12.3 \%$ on plots treated with $2.24 \mathrm{~kg} /$ ha of the herbicide after 2 and 3 years, respectively. Apparent only after 3 years because of inherent variation in species distribution, notable increases also occurred in the percentage of plains bristlegrass (Setaria leucopila) and southwestern bristlegrass ( S. scheelei) in tebuthiuron-treated plots.

Based on grazing value, there was no difference in the relative proportions of species in the grass stand, the first growing season following tebuthiuron application near Sinton compared to untreated plots (data not shown). From 9.5 to $15 \%$ of the botanical composition, based on foliar cover, was initially afforded by grasses of good to excellent grazing value, primarily species of Chloris and Setaria. By 2 years after initiation of the study, with the plots protected from grazing and with higher than average rainfall $(109 \mathrm{~cm}$ as compared to the 30 -year annual average of $72.5 \mathrm{~cm}$ ), the proportions of grasses of good to excellent grazing value had increased to $27 \%$ on the untreated plots, with $30 \%$ of the stand afforded by species of poor grazing value. Where $2 \mathrm{~kg} /$ ha of tebuthiuron were applied, the proportion of grasses of good to excellent grazing value in the stand $(22 \%)$ was similar to that on untreated plots, but only $8 \%$ of the grass stand was afforded by species of poor grazing value. Due to the heavy cover of huisache, brush control levels were not satisfactory where $2 \mathrm{~kg} /$ ha of tebuthiuron were applied (Scifres et al. 1978). However, where $3.36 \mathrm{~kg} /$ ha of the herbicide were applied, $81 \%$ canopy reduction of huisache resulted, compared to $51 \%$ with the low rate. Where the high tebuthiuron rate was applied, multiflowered false-rhodesgrass and Bell rhodesgrass (Chloris gayana) afforded $72 \%$ of the botanical composition and occurred in roughly equal proportions. Both species are of good to excellent grazing value.

At 18 months after tebuthiuron application near Tilden, grasses of good grazing value represented $24 \%$ of the grass coverage based on foliar contacts (data not shown). Where $1 \mathrm{~kg} /$ ha of tebuthiuron was applied, the more desirable grasses afforded $34 \%$ of the cover, and they afforded $40 \%$ of the cover where $2.24 \mathrm{~kg} / \mathrm{ha}$ of the herbicide were applied. As with the other locations, species of Chloris, hooded windmillgrass (Chloris cucullata), and Bell rhodesgrass represented the major increase in grass cover on the Tilden location.

Based on these data and visual observations, members of the genus Chloris appear to be highly tolerant of tebuthiuron applications. Also, as noted at the LaPryor location, several Setaria spp., including plains and southwestern bristlegrasses, species of good grazing value, appeared to increase under treatment but not so dramatically as did Chloris spp.

\section{Herbaceous Standing Crop}

Regardless of year following application, plots treated with $2.24 \mathrm{~kg} / \mathrm{ha}$ or more tebuthiuron supported significantly higher grass standing crops than did untreated plots near LaPryor (Table 2). However, $1.12 \mathrm{~kg} /$ ha of the herbicide did not result in higher standing grass crop than on untreated plots, regardless of year of evaluation. Herbaceous standing crop differences correlated closely with differential brush response due to herbicide rate. At least $2.24 \mathrm{~kg} /$ ha were requircd for control of most woody species near LaPryor (Scifres et al. 1978). Although relative influ- ence of treatment effect was apparent regardless of year, expected influences of rainfall conditions on absolute forage standing crop were apparent.

All rates of tebuthiuron reduced broadleaf standing crop the first and second growing season after treatment ncar LaPryor (Table 2). Treatment effect was less pronounced after 3 years, but broadleaf standing crop was significantly reduced on plots receiving $2.24 \mathrm{~kg} /$ ha or more tebuthiuron. At 1 year after treatment, 11 species of broadleaves were present in the untreated plots. Of these, western ragweed (Ambrosia psilostachya), common ragweed (Ambrosia artemisiifolia), Arkansas dozedaisy (Aphanostephus skirrhobasis), Lindheimer croton (Croton glandulosa var. lindheimeri), Texas croton (Croton texensis), common dogweed (Dyssodia pentachaeta), prairie peppergrass (Lepidium densiflorum), common lantana (Lantana horrida), and Lindheimer bladderpod (Lesquerella lindheimeri) were the primary species encountered on untreated plots or on those treated with the low rates of tebuthiuron. Texas croton and Lindheimer bladderpod were the only forbs encountered on the plots treated with 3.36 or $4.48 \mathrm{~kg} / \mathrm{ha}$ of the herbicide the first year after application. The same primary species were encountered the second year of study. Due to dry conditions during the summer of the third year after treatment, the primary species encountered in August were western ragweed and gland tooth gumweed (Grindelia microcephala var. adenodonta), regardless of treatment.

The trend in forage production changes following tebuthiuron application near Tilden (Table 3) was somewhat dif-

Table 3. Herbaceous standing crop (kg/ha) on July 1977 after aerial application of tebuthiuron pellets to whitebrush on November 20 and 21, 1975 near Tilden, Texas.

\begin{tabular}{ccc}
\hline \hline \multirow{2}{*}{$\begin{array}{c}\text { Tebuthiuron } \\
\text { rate } \\
(\mathrm{kg} / \mathrm{ha})\end{array}$} & Herbaceous standing crop $(\mathrm{kg} / \mathrm{ha})$ \\
\cline { 2 - 3 } & Grasses & Broadleaves \\
\hline 0 & 1,298 & 381 \\
1 & 2,154 & 245 \\
2 & 2,561 & 120 \\
\hline
\end{tabular}

ferent from that near LaPryor. At 17 months after aerial application of only $1 \mathrm{~kg} /$ ha near Tilden, grass standing crop was increased by $66 \%$ with only slightly higher standing crop where $2 \mathrm{~kg}$ / ha were applied. This response was attributed to the higher susceptibility of the whitebrush stand near Tilden compared to the mixed-brush communities at other locations. One to $2 \mathrm{~kg}$ / ha of tebuthiuron will apparently control more than $90 \%$ of the whitebrush (Scifres et al. 1978) but higher rates are required for certain species of Acacia and for honey mesquite, which typically occur in upland mixed brush. Also, although only $1.55 \mathrm{~cm}$ of rainfall occurred the first 2 months following treatment, $95.5 \mathrm{~cm}$ were received the year of herbicide application near Tilden with $24 \mathrm{~cm}$ received from March through early June. The study area normally receives about $56 \mathrm{~cm}$ of rainfall annually. As at other locations, forb standing crop was reduced by the tebuthiuron treatments (Table 3 ).

More than 20 forb species were encountered at the Tilden site, of which common ragweed was most common. Since $2 \mathrm{~kg} / \mathrm{ha}$ or less were applied at Tilden, the reduction in the forb population was not severe, compared to results near LaPryor. Arkansas dozedaisy, marestail (Conyza canadensis), prairie peppergrass, yellow woodsorrcl (Oxalis dillenii), Texas groundcherry (Physalis virginiana), prairie cone- 
flower (Ratibida columnaris), Texas snoutbean (Rhyncosia texana), silverleaf nightshade (Solanum eleagnifolium), and slender vervain (Verbena hallii) were common to all plots at the final evaluation. Distribution of the remaining species apparently was affected more by localized site conditions than by treatment effect.

Species diversity of forbs was considerably greater at Sinton than at LaPryor, with 25 primary species encountered. Common ragweed, heath aster (Aster ericoides), erect dayflower (Commelina erecta), marestail, Texas croton, Florida snakecotton (Froelichia floridana), Texas geranium (Geranium texanum), common broomweed (Xanthocephalum dracunculoides), camphorweed (Heterotheca subaxillaris), prairie peppergrass, spotted beebalm (Monarda punctata), Texas groundcherry, Texas snoutbean, blackeyed susan (Rudbeckia divergens), Karnes sensitivebriar (Schrankia latidens), silverleaf nightshade, and crownbeard (Verbesina mictoptera) were most common in untreated plots and those treated with $2 \mathrm{~kg} / \mathrm{ha}$ of the tebuthiuron pellets. At the final evaluation, primary forb species encountered where $3.36 \mathrm{~kg} /$ ha of the herbicide were applicd were common ragweed, erect dayflower, marestail, Texas croton, Karnes sensitivebriar, crownbeard, and slender vervain.

Based on these results and efficacy data (Scifres et al.
1978), tebuthiuron appears to hold promise for range improvement in South Texas where mixed-brush and whitebrush stands pose the primary management problems. Based on forage response, 1 to $2 \mathrm{~kg}$ / ha are required for range improvement relative to increasing standing crop and relative proportions of species of good grazing value. If the high rates are required for brush control (based on species present) and whitc-tailed deer (Odocoileus virginianus) habitat is considered, a patterned application would probably be advisable to assure an adequate forb population for the first and second years after tebuthiuron application.

\section{Literature Cited}

Gould, F. W., and T. W. Box. 1965. Grasses of the Texas Coastal Bend. Texas A\&M Univ. Press, College Station. 189 p.

Hoffman, G. O., J. D. Rodgers, B. J. Ragsdale, and R. V. Miller. 1970. Know your grasses. Texas Agr. Ext. Serv. B-182. 47 p.

Robison, E. D., and B. T. Cross. 1970. Redberry juniper control and grass response following aerial application of picloram. Texas Agr. Exp. Sta. PR-2805. In: Brush Research in Texas. Consol. Prog. Rep. $2801-2828$.

Scifres, C. J., G. P. Durham, and J. L. Mutz. 1977. Range forage production and consumption following aerial spraying of mixed brush. Weed Sci. 25:48-54

Scifres, C. J., J. L. Mutz, and W. T. Hamilton. 1978. Control of mixed brush with tebuthiuron. J. Range Manage. (In press). 